\title{
The important role of breast microbiota in breast cancer
}

\author{
Kar-Yan Su ${ }^{1, * \#, ~ W a i-L e n g ~ L e e ~}{ }^{1}$ and Vinod Balasubramaniam ${ }^{2, * \#}$ \\ 1 School of Science, Monash University Malaysia, 47500 Bandar Sunway, Selangor Darul Ehsan, Malaysia; \\ cayenne.sky@gmail.com \\ 2 Infection and Immunity Research Laboratory, Jeffrey Cheah School of Medicine and Health Sciences, \\ Monash University Malaysia, 47500 Bandar Sunway, Selangor, Malaysia; \\ vinod.balasubramaniam@monash.edu \\ * Correspondence: cayenne.sky@gmail.com (K.-Y.S.), vinod.balasubramaniam@monash.edu (V.B.); Tel. \\ (+60355146000 (extension:61366) (V.B.) \\ \# Equal contribution
}

\begin{abstract}
One in eight women will be diagnosed with breast cancer (BC) in their lifetime, resulting in over 2 million cases annually. BC is the most common cancer among women. Unfortunately, the etiology of majority of cases remains unknown. Recently, evidence has shown that the human microbiota plays an important role in health and disease. Intriguingly, studies have revealed the presence of microorganisms in human breast tissue, which was previously presumed to be sterile. Next-generation sequencing technologies have paved way for the investigation of breast microbiota, uncovering bacterial signatures that are associated with $\mathrm{BC}$. Some of the bacterial species were found to possess pro-carcinogenic and/or anti-carcinogenic properties, suggesting that the breast microbiota has potentially crucial roles in maintenance of breast health. In this review, we summarize the recent findings on breast tissue microbiota and its interplay with BC. Bacterial signatures identified via next-generation sequencing as well as their impact on breast carcinogenesis and cancer therapies are reviewed. Correlation of breast tissue microbiota and other factors, such as geographical and racial differences, in BC is discussed. Additionally, we discuss the future directions of research on breast microbiota as well as its potential role in prevention, diagnosis and treatment of BC.
\end{abstract}

Keywords: breast cancer; microbiota; bacteria; dysbiosis; pro-carcinogenic; anti-carcinogenic; genetics; next-generation sequencing; cancer treatments; cancer prevention

\section{Introduction}

Breast cancer $(\mathrm{BC})$ is the most common cancer among women and the second most frequent cancer overall with over 2 million cases globally each year [1]. In fact, one in eight women will be diagnosed with BC in their lifetime. Despite the substantial progress in treatment and diagnosis, BC is still the leading cause of cancer death among women worldwide [2]. Due to the complexity of cancer which involves a multitude of genomic and physiological changes, the precise etiology of majority of BC is still unknown. Moreover, only a portion of those with genetic predisposition to BC and those exposed to known environmental risk factors developed the disease [3]. At least $70 \%$ of $\mathrm{BC}$ cases happen in women with average risk and existing prediction models offer poor risk discrimination $[4,5]$. This suggests the urgent need to identify other contributing factors. Indeed, one such factor that has garnered attention recently is the human microbiota which consists of trillions of bacteria, viruses, archaea and eukaryotes of more than 10,000 different species that colonize human tissue at numerous body sites and contributes to human development [6]. Perturbation of the 
dynamic microbial communities, termed dysbiosis, has been increasingly shown to correlate with many disorders including acute and chronic diseases ranging from obesity [7] to autism spectrum disorders $[8,9]$ as well as BC $[10,11]$.

Dysbiosis has also been linked to other types of cancer such as gastric adenocarcinoma caused by the well-studied Helicobacter pylori [12] and colorectal cancer associated with the emerging role of certain microbiomic profiles, including Fusobacterium [13,14]. It is becoming progressively evident that both discrete bacterial species and community composition can exert either pathogenic effects that lead to diseases or probiotic effects which maintain the health. In fact, infection with one or more microorganisms or viruses is the third largest cause of cancer, resulting in at least $20 \%$ of cases $[15,16]$. In relation to this, the human microbiota formed by the huge amount and diversity of microorganisms and viruses may have an underestimated association with cancer due to unrecognized mechanisms or infections [15]. Furthermore, mounting evidence indicates that microbial shifts are associated with cancer development and aggressiveness [17] whereas restoring the normal microbiota or removing the causative organism can reverse this process $[18,19]$. Hence, knowledge on the microbial signatures associated with specific cancers can offer insights into etiology, prevention, diagnosis and treatment.

The distinct nature of microbiota in each body niche indicates an organ specificity to microbial effects on carcinogenesis. It was previously believed that the breast tissue was sterile. However, microbiome analyses of breast tissue and milk have shown that the human breast harbors diverse and unique microbiota $[11,20,21]$, which is at least partly originated from microorganisms reaching the ducts from the skin via nipple-oral contact through lactation and/or sexual contact as well as translocation of the gut microorganisms [22,23]. In this regard, it has been suggested that the breast microbiota supports the maintenance of healthy breast tissue by processes such as stimulating resident immune cells and degrading carcinogens through their metabolic activity [11]. Intriguingly, recent studies have correlated breast microbiota with BC and demonstrated pro-carcinogenic and/or anti-carcinogenic properties of certain bacterial species, suggesting a potentially important role of the microbiota in the disease development [23,24]. Furthermore, microbiota has also been found to affect the efficacy and toxicity of cancer treatments, signifying a novel strategy to exploit the microbiota to improve efficacy and reduce toxicity of the therapies. Albeit the study of breast microbiota is still in its infancy, these findings have provided an insight on the impact of breast microbiota on BC and highlighted the rationale for further exploring its role in the disease. In this review, we summarize the recent findings on breast tissue microbiota and its interplay with $\mathrm{BC}$ (Figure 1). Bacterial signatures of $B C$ patients and healthy individuals identified via next-generation sequencing as well as their potential roles in breast carcinogenesis and cancer therapies are reviewed. Correlation of breast tissue microbiota and other factors, such as geographical and racial differences, in BC is also discussed. In addition, we discuss the future directions of investigations on breast microbiota as well as its impact on the prevention, diagnosis and treatment of BC. 


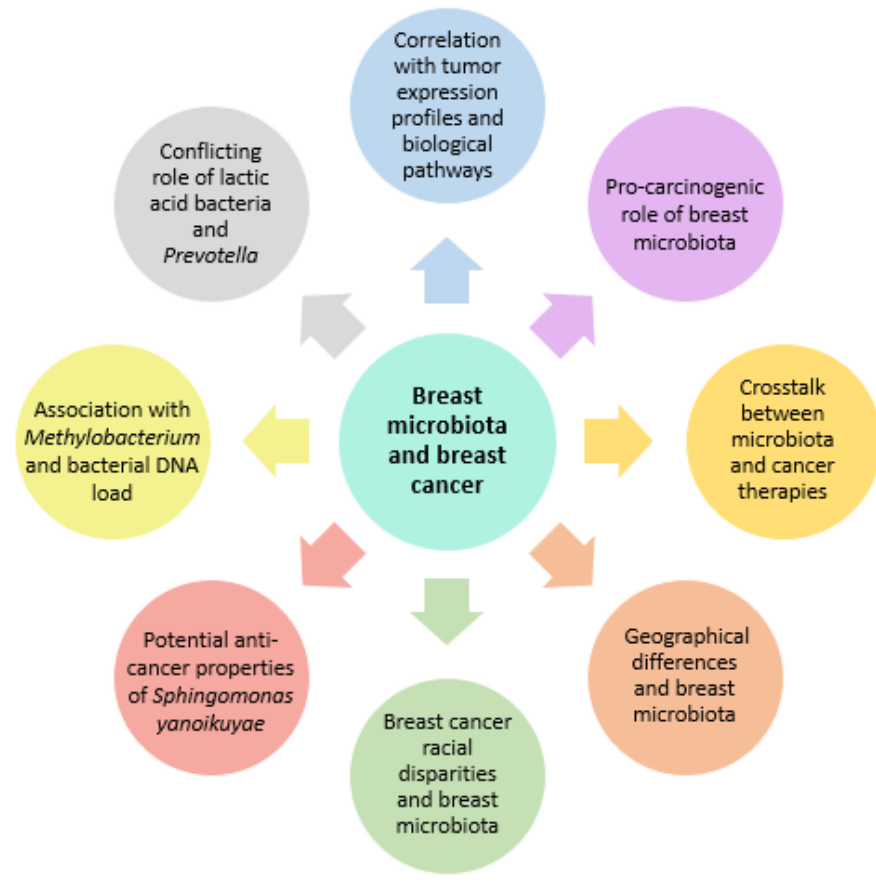

Figure 1. Interplay between breast microbiota and breast cancer.

\section{Breast microbiota and breast cancer}

Dysbiosis denotes the abnormal composition in microbial community of an organism, which can occur when proportions of certain species alter within the community. It hampers the symbiotic relationships in microbial community and disrupts the usual function of the community. Even though the largest microbial community of human resides in the gastrointestinal tract, it is necessary to consider the role of breast microbiota in $\mathrm{BC}$ due to the association between dysbiosis and the disease [10,11]. Hieken et al. [23] showed that the breast tissue had a microbiome which was different from that of the overlying breast skin and with a greater species richness. This indicates that though the breast tissue microbiome might be originated from the skin microbiome, breast tissue has a distinct ecosystem and environment. These differences may be caused by variances in tissue microenvironments, for instance oxygen levels and $\mathrm{pH}$, which facilitate the relative dominance of specific taxa. In addition, the breast tissue microenvironment may be associated with the breast health which allows the growth of certain bacterial species that are otherwise unable to grow in a different health condition.

Notably, unique microbial signatures including bacterial, viral, fungal and parasitic signatures present in breast tumor tissues have been associated with the four major types of $\mathrm{BC}$, namely endocrine receptor (ER) (estrogen or progesterone receptor) positive, human epidermal growth factor receptor 2 (HER2) positive, triple positive (estrogen, progesterone and HER2 receptors positive) and triple negative (estrogen, progesterone and HER2 receptors negative) BCs $[25,26]$. Moreover, the alteration in breast microbiota correlates with the histological grade [27] (Table 1) of 
the disease. These alterations affect functional changes, such as the up-regulation of glycerophospholipid and ribosome biogenesis as well as the down-regulation of flavonoid biosynthesis, as the grade of $\mathrm{BC}$ increases [27]. Hence, these suggest the potential use of microbial and pathway signatures as biomarkers for diagnosis and staging of BC. Recently, the role of breast tissue microbiota in $\mathrm{BC}$ has been investigated. The results of clinical studies on $\mathrm{BC}$ and human breast microbiota in which the bacterial 16S rRNA gene was sequenced are summarized in Table 1, highlighting the predominant bacteria found in breast tissue as well as the differentially abundant bacteria identified in healthy individuals and patients with $B C$ or benign tumor. Most of the investigations have demonstrated a predominance of the phyla Proteobacteria and Firmicutes in breast tissue $[11,21,24,25]$ (Table 1). Nevertheless, the functionality of breast microbiota may ultimately have a more essential role in BC than its composition. Studies have shown the ability of microbiota to regulate chronic inflammation and immunity, genomic stability and DNA damage as well as metabolic function of the host which may modulate the risk of BC. These roles and the possible mechanisms of specific breast microbiota that impacts $\mathrm{BC}$ development are further discussed in the following sections of this review. 
Table 1. Human studies on breast microbiota in relation to breast cancer.

\begin{tabular}{|c|c|c|c|c|}
\hline Study & $\begin{array}{l}\text { Sampling materials and sample } \\
\text { size }\end{array}$ & $\begin{array}{l}\text { Microbiota detection and } \\
\text { OTU picking method }\end{array}$ & $\begin{array}{l}\text { Predominant bacteria } \\
\text { in breast tissue }\end{array}$ & $\begin{array}{l}\text { Differentially abundant bacteria in } \\
\text { BC, benign or control }\end{array}$ \\
\hline $\begin{array}{c}\text { Xuan et al., } 2014 \\
\text { [11] }\end{array}$ & $\begin{array}{l}\text { Breast tumor tissue and paired } \\
\text { normal adjacent breast tissue from } \\
20 \mathrm{ER}+\mathrm{BC} \text { patients }\end{array}$ & $\begin{array}{l}\text { Pyrosequencing gDNA } \\
\text { amplified 16S V4 rDNA, } \\
\text { QIIME: Greengenes database }\end{array}$ & $\begin{array}{l}\text { Proteobacteria } \\
\text { Firmicutes } \\
\text { Actinobacteria } \\
\text { Bacteroidetes } \\
\text { Verrucomicrobia }\end{array}$ & $\begin{array}{l}\text { Breast tumor tissues: } \\
\text { Methylobacterium radiotolerans } \\
\text { Normal adjacent breast tissues of BC: } \\
\text { Sphingomonas yanoikuyae }\end{array}$ \\
\hline $\begin{array}{l}\text { Urbaniak et al., } \\
\quad 2014[21]\end{array}$ & $\begin{array}{l}\text { Breast tumor tissue and normal } \\
\text { breast tissue from } 81 \text { women: } 43 \\
\text { Canadian ( } 27 \mathrm{BC}, 11 \text { benign, } 5 \\
\text { healthy) and } 38 \text { Irish ( } 33 \mathrm{BC}, 5 \\
\text { healthy) }\end{array}$ & $\begin{array}{l}\text { Ion Torrent V6 16S rRNA } \\
\text { sequencing, QIIME: } \\
\text { Ribosomal Database Project } \\
\text { SeqMatch tool }\end{array}$ & $\begin{array}{l}\text { Proteobacteria } \\
\text { Firmicutes } \\
\text { Actinobacteria } \\
\text { Bacteroidetes } \\
\text { Verrucomicrobia } \\
\text { Fusobacteria } \\
\text { Deinococcus-Thermus }\end{array}$ & $\begin{array}{l}\text { Breast tumor tissues: } \\
\text { Escherichia coli }\end{array}$ \\
\hline $\begin{array}{l}\text { Urbaniak et al., } \\
\quad 2016[24]\end{array}$ & $\begin{array}{l}\text { Normal adjacent breast tissue: } 58 \\
\text { patients ( } 45 \mathrm{BC}, 13 \text { benign) } \\
\text { Normal breast tissue: } 23 \text { healthy } \\
\text { women }\end{array}$ & $\begin{array}{l}\text { 16S V6 rRNA amplicon } \\
\text { sequencing, QIIME: SILVA } \\
\text { database }\end{array}$ & $\begin{array}{l}\text { Proteobacteria } \\
\text { Firmicutes }\end{array}$ & $\begin{array}{l}\text { Normal adjacent breast tissues of BC: } \\
\text { Bacillus } \\
\text { Staphylococcus } \\
\text { Enterobacteriaceae (unclassified) } \\
\text { Bacteroidetes (unclassified) } \\
\text { Comamondaceae (unclassified) } \\
\text { Normal breast tissues: } \\
\text { Lactococcus } \\
\text { Streptococcus } \\
\text { Prevotella } \\
\text { Corynebacterium }\end{array}$ \\
\hline
\end{tabular}


Table 1. Cont.

\begin{tabular}{|c|c|c|c|c|}
\hline Study & $\begin{array}{l}\text { Sampling materials and sample } \\
\text { size }\end{array}$ & $\begin{array}{l}\text { Microbiota detection and } \\
\text { OTU picking method }\end{array}$ & $\begin{array}{l}\text { Predominant bacteria } \\
\text { in breast tissue }\end{array}$ & $\begin{array}{l}\text { Differentially abundant bacteria in } \\
\text { BC, benign or control }\end{array}$ \\
\hline $\begin{array}{l}\text { Hieken } \text { et al., } \\
\quad 2016[23]\end{array}$ & $\begin{array}{l}\text { Normal adjacent breast tissue: } 13 \\
\text { benign and } 15 \text { invasive BC (all ER+ } \\
\text { and PR+, } 29 \% \text { HER2+) }\end{array}$ & $\begin{array}{l}16 \mathrm{~S} \text { V3-V5 rDNA } \\
\text { hypervariable taq } \\
\text { sequencing, IM-TORNADO: } \\
\text { Greengenes database }\end{array}$ & $\begin{array}{l}\text { Proteobacteria } \\
\text { Firmicutes } \\
\text { Actinobacteria } \\
\text { Bacteroidetes }\end{array}$ & $\begin{array}{l}\text { Normal adjacent breast tissues of BC: } \\
\text { Fusobacterium } \\
\text { Lactobacillus } \\
\text { Atopobium } \\
\text { Hydrogenophaga } \\
\text { Gluconacetobacter }\end{array}$ \\
\hline $\begin{array}{l}\text { Wang et al., } \\
2017 \text { [10] }\end{array}$ & $\begin{array}{l}\text { Breast tumor tissue and paired } \\
\text { normal adjacent breast tissue: } 57 \mathrm{BC} \\
\text { patients } \\
\text { Normal breast tissue: } 21 \text { healthy } \\
\text { women }\end{array}$ & $\begin{array}{l}\text { Illumina } 16 \mathrm{~S} \text { V3-V4 rRNA } \\
\text { amplification, QIIME: } \\
\text { Greengenes database }\end{array}$ & Not specified & $\begin{array}{l}\text { Breast tumor tissues: } \\
\text { Alcaligenaceae } \\
\text { Normal breast tissues: } \\
\text { Methylobacterium }\end{array}$ \\
\hline $\begin{array}{l}\text { Thompson } e t \\
\text { al., } 2017[28]\end{array}$ & $\begin{array}{l}668 \text { breast tumor tissues (HER2+, } \\
\text { ER+, TNBC) and } 72 \text { normal } \\
\text { adjacent tissues from TCGA } \\
\text { Breast tissues from } 6 \text { ER+ patients } \\
\text { submitted to TCGA }\end{array}$ & $\begin{array}{l}\text { 16S V3-V5 rRNA gene } \\
\text { sequencing, IM-TORNADO: } \\
\text { Greengenes database }\end{array}$ & $\begin{array}{l}\text { Proteobacteria } \\
\text { Firmicutes } \\
\text { Actinobacteria }\end{array}$ & $\begin{array}{l}\text { Breast tumor tissues: } \\
\text { Proteobacteria } \\
\text { Mycobacterium fortuitum } \\
\text { Mycobacterium phlei } \\
\text { Normal adjacent breast tissues of BC: } \\
\text { Actinobacteria } \\
\text { Escherichia coli } \\
\text { Haemophilus influenzae }\end{array}$ \\
\hline
\end{tabular}


Table 1. Cont

\begin{tabular}{|c|c|c|c|c|}
\hline Study & $\begin{array}{l}\text { Sampling materials and sample } \\
\text { size }\end{array}$ & $\begin{array}{l}\text { Microbiota detection and } \\
\text { OTU picking method }\end{array}$ & $\begin{array}{l}\text { Predominant bacteria } \\
\text { in breast tissue }\end{array}$ & $\begin{array}{l}\text { Differentially abundant bacteria in } \\
\text { BC, benign or control }\end{array}$ \\
\hline \multirow{10}{*}{$\begin{array}{l}\text { Meng et al., } \\
2018 \text { [27] }\end{array}$} & \multirow{10}{*}{$\begin{array}{l}\text { Breast tumor tissue: } 72 \mathrm{BC} \text {, } \\
22 \text { benign }\end{array}$} & \multirow{10}{*}{$\begin{array}{l}\text { 16S V1-V2 rRNA gene } \\
\text { amplicon sequencing, } \\
\text { QIIME: Greengenes database }\end{array}$} & \multirow{10}{*}{$\begin{array}{l}\text { Proteobacteria } \\
\text { Firmicutes } \\
\text { Actinobacteria } \\
\text { Bacteroidetes }\end{array}$} & Malignant breast tumor tissues: \\
\hline & & & & Proteobacteria \\
\hline & & & & Propionicimonas \\
\hline & & & & Micrococcaceae \\
\hline & & & & Caulobacteraceae \\
\hline & & & & Rhodobacteraceae \\
\hline & & & & Nocardioidaceae \\
\hline & & & & Methylobacteriaceae \\
\hline & & & & $\begin{array}{l}\text { Malignant breast tumor tissues with } \\
\text { lower histological grade: } \\
\text { Bacteroidaceae }\end{array}$ \\
\hline & & & & $\begin{array}{l}\text { Malignant breast tumor tissues with } \\
\text { higher histological grade: } \\
\text { Agrococcus }\end{array}$ \\
\hline \multirow{7}{*}{$\begin{array}{l}\text { Costantini } e t \\
\text { al., } 2018 \text { [29] }\end{array}$} & \multirow{7}{*}{$\begin{array}{l}\text { Breast tumor tissue and paired } \\
\text { normal adjacent breast tissue: } 16 \text { BC } \\
\text { patients }\end{array}$} & $16 \mathrm{~S} V 2, \mathrm{~V} 3, \mathrm{~V} 4, \mathrm{~V} 6+7, \mathrm{~V} 8$, and & \multirow{7}{*}{$\begin{array}{l}\text { Proteobacteria } \\
\text { Firmicutes } \\
\text { Actinobacteria } \\
\text { Bacteroidetes }\end{array}$} & Breast tumor tissues: \\
\hline & & \multirow{6}{*}{$\begin{array}{l}\text { V9 rRNA gene amplicon } \\
\text { sequencing, Ion } \\
\text { Reporter Software: } \\
\text { MicroSEQ(R) 16S Reference } \\
\text { Library and Greengenes } \\
\text { database }\end{array}$} & & Methylobacterium \\
\hline & & & & Ralstonia \\
\hline & & & & Normal adjacent breast tissues of $\mathrm{BC}$ : \\
\hline & & & & Sphingomonas \\
\hline & & & & Methylobacterium \\
\hline & & & & \\
\hline
\end{tabular}


Table 1. Cont.

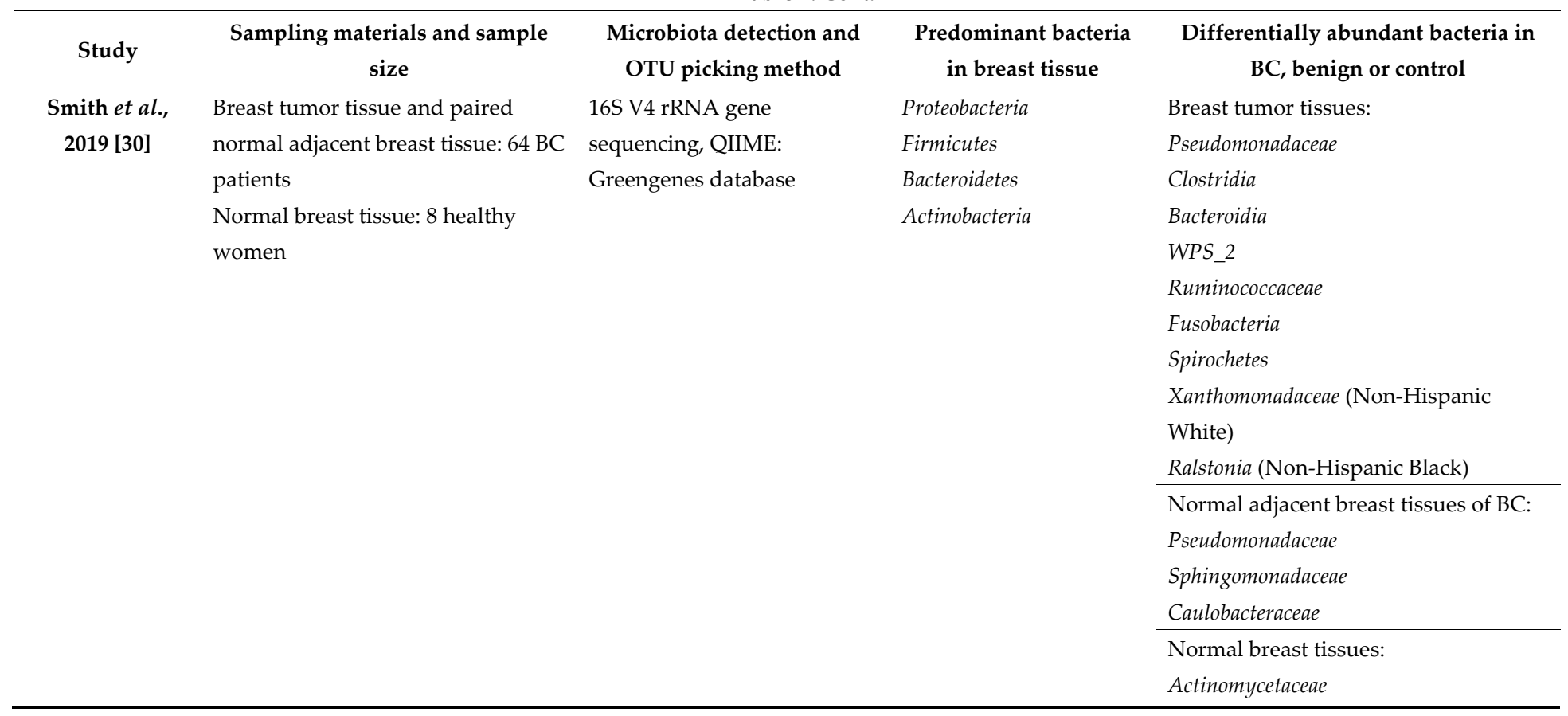

BC: breast cancer; ER+: estrogen receptor positive; PR+: progesterone receptor positive; HER2+: human epidermal growth factor receptor 2 positive; TNBC: triple negative breast cancer; TCGA: The Cancer Genome Atlas; OTU: operational taxonomic unit; QIIME: Quantitative Insights Into Microbial Ecology; IM-TORNADO: Illinois Mayo Taxon Organization from RNA Dataset Operations. 


\section{Breast microbiota is correlated with tumor expression profiles and biological pathways}

Thompson et al. [28] utilized BC data from The Cancer Genome Atlas (TCGA) to characterize breast microbiota and investigate the correlation between these OTUs and host tumor expression profiles. Geneset enrichment indicated that the tumor gene expression was associated with Listeria fleischmannii and to a smaller extent, with Neisseria subflava. L. fleischmannii was found to be more strongly correlated with expression profiles of genes involving epithelial-to-mesenchymal transition, which is implicated in tumor progression with metastatic expansion and the development of tumor cells with stem cell properties that are essential in resistance to cancer therapies [31-33]. On the other hand, Haemophilus influenzae was associated with genes representing pathways essential to tumor growth, which are E2F transcription factors, G2M checkpoint and mitotic spindle assembly [28]. $\mathrm{H}$. influenzae is an opportunistic pathogen that has been shown to induce inflammatory immune response and enhance tumor growth in lung cancer murine models $[34,35]$. The increased presence of this bacterium in non-cancerous adjacent samples indicated that it may primarily reside in the neighboring stromal tissue. Indeed, the oxidative tumor environment might prohibit $\mathrm{H}$. influenzae penetrance as the bacterium has been shown to be susceptible to $\mathrm{H}_{2} \mathrm{O}_{2}$. Taken together, these findings have shed light onto the possible mechanisms in which breast microbiota affects BC development, whereby certain bacterial species exhibit their pro-carcinogenic roles by modulating the host gene expression.

Meanwhile, Hieken et al. [23] examined the functional roles of the breast microbiota using KEGG pathways for analysis and found 6 differentially abundant pathways between malignant and benign disease states. The pathways involving methionine and cysteine metabolism, C5-branched dibasic acid metabolism, fatty acid biosynthesis and glycosyltransferases were depleted in patients with malignant disease. Intriguingly, methionine dependence is a common metabolic defect in many cancers and it has been proposed that cancer progression can be reversed by depleting methionine with a methionine-restricted diet or methioninase [36,37]. Thus, the results indicated that the breast microbiota may also be involved in breast carcinogenesis by modulating the biological pathways of the host. The secretion of bacterial metabolites which enter the circulation to reach their target cells is a main pathway in microbiome-to-host signaling $[38,39]$. In regard to this, the role of bacterial metabolites is similar to the human hormones that are synthesized in a gland or an organ and transferred to other anatomical sites, where they exert their biological effects. These blood-borne microbial metabolites such as short-chain fatty acids [40,41], lithocholic acid [42-44], deconjugated estrogens $[45,46]$ and cadaverine [47] were shown to regulate the behavior of BC. Such bacterial metabolites have profound effect on mitochondrial metabolism. Notably, metabolites also modulate other metabolic processes, for instance lipid metabolism [48].

\section{Pro-carcinogenic role of breast microbiota}

A study was performed by Urbaniak et al. [24] to determine whether the breast tissue microbiome could play a role in regulating the risk of $\mathrm{BC}$ development. Bacterial signatures were found to be statistically different between the normal adjacent tissue in BC women and control tissue. Higher relative abundances of Enterobacteriaceae, Bacillus, Staphylococcus, Bacteroidetes and Comamondaceae were found in BC patients, while Lactococcus, Streptococcus, Prevotella, Corynebacterium and Micrococcus were the most abundant in healthy controls [24]. Escherichia coli strains, which belong 
to the family Enterobacteriaceae, are known to harbor pks pathogenicity island that encodes the machinery to produce the genotoxin colibactin. The ability of these $p k s$-positive strains to induce chromosomal instability and DNA double-stranded breaks $[49,50]$ through colibactin has been linked to colon cancer [51,52]. Hence, this led Urbaniak et al. [24] to isolate the bacteria from normal adjacent tissue of BC patients and evaluate for their abilities to cause DNA damage via histone-2AX (H2AX) phosphorylation $(\gamma-\mathrm{H} 2 \mathrm{AX})$ assay. The isolated E. coli and Staphylococcus epidermidis induced DNA double-stranded breaks in HeLa cells [24], which may explain their higher abundances in cancer patients. Moreover, Thompson et al. [28] have also reported that $E$. coli was more abundant in breast tissues and was shown in higher abundance within non-cancerous adjacent breast tissues. Similarly, in a previous study by Urbaniak et al. [21], a greater abundance of the cancer-promoting E. coli was also observed in breast tissues from cancer patients compared to healthy controls.

Women who are genetically susceptible to BC or have mutations in DNA checkpoint or DNA repair machinery may be more prone to bacterially induced DNA damage. Thus, they might be at a greater risk of developing BC than women without these mutations, even when the same harmful microbes are present in their mammary glands [24]. These findings suggest that both the presence of mutations in DNA checkpoint or DNA repair machinery and the presence of pro-carcinogenic bacteria with DNA damaging properties within the breast microbiota may be a useful indicator of $\mathrm{BC}$ risk. Furthermore, Micrococcus, which was relatively abundant in healthy controls, as well as Propionibacterium, which had no difference in relative abundances between healthy controls and cancer patients, did not produce the DNA double-stranded breaks [24]. Therefore, these results further substantiated the association between BC and bacteria with DNA damaging properties that are highly abundant within the breast microbiota. On the other hand, although Bacillus did not inflict the DNA double-stranded breaks, Bacillus cereus cultured in the study by Urbaniak et al. [24] may possess other pro-carcinogenic effects and promote tumor development by metabolizing progesterone [53,54].

In Hieken et al.'s [23] study, the breast tissue microbiome was differentially abundant with the phyla Proteobacteria, Firmicutes, Actinobacteria and Bacteroidetes in descending order, similar with the findings from Urbaniak et al. [21]. The authors also demonstrated that the microbial communities were notably distinct between the normal breast tissue adjacent to invasive cancer and that adjacent to benign disease. Malignancy has been found to be associated with enrichment of taxa with lower prevalence such as the genera Fusobacterium, Lactobacillus, Atopobium, Hydrogenophaga and Gluconacetobacter. In fact, Fusobacterium has been linked to other epithelial malignancies, including colorectal cancer, by releasing virulence factors and producing a pro-inflammatory environment that progresses carcinogenesis [14,55-57]. Although the authors attributed menopausal status and age of patients as possible confounders of the observed differences, these results indicated the potential use of the microbial signatures as biomarkers for BC diagnosis.

\section{Crosstalk between microbiota and cancer therapies}

Dysbiosis can profoundly impact both cancer pathogenesis and its therapeutic outcome. Particularly, the regulation of therapeutic outcomes is closely associated with the ability of gut microbiota to metabolize anti-tumoral compounds and to modulate host's immune response as well as inflammation pathways [58]. As a result, this may explain the strong involvement of microbiota composition in affecting the effectiveness of both chemotherapy and immunotherapy [59]. Mounting 
evidence suggests that gut microbiota affects the chemotherapy efficacy and toxicity by regulating the metabolism, translocation and immune response to the drugs [60]. Thus, it is likely that the local microbiota of the breast may have a distinct role in modulating chemotherapeutic effectiveness in addition to the known role of gut microbiota in regulating the efficacy of chemotherapeutics. This would indicate that the breast microbiota may play a critical role in the development of personalized cancer treatment, which can be targeted to enhance efficacy and reduce toxicity of existing chemotherapy agents. Hence, a greater insight into the impact of the microbiota on chemotherapeutic drugs is highly required. Moreover, the gut microbiota composition has also been found to modulate the toxic side effects caused by immunotherapy. It has been observed that toxic side effects in patients treated with anti-CTLA4 antibody are regulated by an increased abundance of Firmicutes, for instance Faecalisbacterium, as well as a decreased abundance of Bacterioides [61,62]. Furthermore, the microbiota has also been shown to correlate with the severity of radiotherapy-induced mucositis $[63,64]$ and protect against radiation-induced toxicity [65]. This suggests the potential use of microbiota-based strategies in early prediction and prevention of radiotherapy-related complications. On the other hand, cancer therapies could also modulate the microbiota. Poly(ADP-ribose) polymerase (PARP) inhibitors, which are drugs that are potentially used as $B C$ treatment $[66,67]$ in future, were found to increase the diversity of gut microbiota $[68,69]$. Therefore, cancer treatments may impact the microbiota positively or negatively, which in turn affect the health of the host. Hence, the effects of cancer therapies on microbiota may have to be further examined.

Additionally, altering microbiota may deeply affect the outcome of anti-cancer therapies. Antibiotics were found to disrupt the microbiota resulting in a decreased response to platinum-based chemotherapies and immunotherapies [70]. This indicates that an intact microbiota is essential for optimal responses to cancer treatments. It has been revealed how tumor-bearing mice, either germfree or with depleted gut microbiota through antibiotics therapy, have no response to oxaliplatin drug treatment. The elucidation is that commensal microbiome members in the gut of the mice may produce TLR agonists, hence promoting an oxidative stress milieu and causing tumor cell death. Consequently, there is a reduced microbiota-dependent ROS production without a healthy gut microbiota, which results in a less effective chemotherapeutic response [70]. Consistently, mice with lung tumors treated with cisplatin in combination with antibiotics, survive less and form bigger tumors. When cisplatin is combined with probiotics, for instance Lactobacilli, mice exhibit an improved response to the therapy. The mechanism involves the stimulation of pro-apoptotic genes within tumor mass and the augmentation of host's immune response [71]. Furthermore, the administration of a particular bacteria, Alistipes shahii, into antibiotic-treated tumor bearing mice, significantly improves the outcome of immunotherapy with restoration of tumor necrosis factor (TNF) production [70]. Probiotics and fecal microbiome transplantation are currently explored as anti-cancer adjuvants to combat dysbiosis following cancer therapies, to enhance chemotherapy and immunotherapy efficacy as well as to both decrease tumor mass and prevent tumor recurrence. Multiple translational studies further substantiate the crucial role of the gut microbiome in regulating the response to immune checkpoint blockade [72-74]. In particular, Routy et al. [72] showed that melanoma patients had a lower survival rate when treated with antibiotics in combination with antiPD1/anti-PD-L1 immunotherapy.

Interestingly, correlative studies have also shown that antibiotic consumption, which reduces the microbiota diversity, increases the risk and recurrence of BC [75-79]. Despite the non-mechanistic nature of these investigations and the possibility for uncontrolled confounding, these studies support 
the observations that the decrease in microbiota diversity increases the risk for BC. Taken together, the microbiota composition of cancer patients and the antibiotic regimens they receive during cancer treatments may have to be well considered. Additionally, the antibiotic consumption history of cancer patients may aid in the prediction of response to cancer therapies. Nonetheless, the effect of antibiotic regimens on the microbiota diversity and therapeutic outcomes in patients receiving cancer treatments needs to be further investigated. On the other hand, since mounting evidence has suggested that microbial dysbiosis is associated with $\mathrm{BC}$, antibiotics may be useful to eradicate the causative organism or restore the normal microbiota to reverse the process. It is therefore essential to identify the factors which are able to affect the microbiota and develop novel strategies to manipulate it, with the main goal of improving the therapeutic outcome. Besides improving the efficacy of cancer therapies, interventions on microbiota may also be crucial to ameliorate cancer therapy-related toxicity $[80,81]$.

\section{Geographical differences affect the breast microbiota}

In another study by Urbaniak et al. [21], the authors investigated the breast tissue microbiota of 81 women with and without cancer from two distant countries, Canada and Ireland to ensure that the findings were not the artifact of a single demographic. Consistent with other studies [11,24,25], Proteobacteria and Firmicutes were the most prevalent phyla among the diverse population of bacteria identified in tissue obtained from sites all around the breast, unlike their lower abundance in other body sites. The authors suggested that these findings may be a result of possible host microbial adaptation in the fatty acid environment of breast tissue, forming its unique microbiota that is distinct from that present at other body sites. The main OTUs identified were from 7 different phyla, Proteobacteria, Firmicutes, Actinobacteria, Bacteroidetes, Verrucomicrobia, Fusobacteria and DeinococcusThermus, where Proteobacteria was the most prevalent, followed by Firmicutes (particularly from the class Bacilli). Notably, the geographical difference between the Canadian and Irish women in the study appears to play a role in shaping the breast tissue microbiomes. The most prevalent taxa in Canadian samples were Bacillus (11.4\%), Acinetobacter (10.0\%), Enterobacteriaceae (8.3\%), Pseudomonas (6.5\%), Staphylococcus (6.5\%), Propionibacterium (5.8\%), Comamonadaceae (5.7\%), Gammaproteobacteria (5.0\%) and Prevotella (5.0\%). Meanwhile, unclassified Enterobacteriaceae (30.8\%), Staphylococcus (12.7\%), Listeria welshimeri (12.1\%), Propionibacterium (10.1\%) and Pseudomonas (5.3\%) were most abundant in the Irish samples [21]. Additionally, culture analysis confirmed the presence of viable bacteria in some of the samples. Although direct comparisons among the two countries are unable to be made because of the different collection and DNA extraction methods applied, further investigations may unveil the effect of geographical differences and perhaps cultural differences on breast microbiota and BC.

\section{Breast cancer racial disparities and breast microbiota}

Smith et al. [30] explored the normal and BC tissue microbiota from non-Hispanic White (NHW) and non-Hispanic Black (NHB) women to characterize distinct microbial signatures in race, stage or tumor subtype. It is well established that NHB women are more prone to be diagnosed with triple negative breast cancer and have the highest risk of $\mathrm{BC}$ death compared to all other ethnic groups [82-84]. The study was the first to reveal differences in breast tissue microbiota between the 
races whereby a higher abundance of genus Ralstonia in breast tumors of NHB women in comparison to NHW tumors, which may explain part of the BC racial disparities. Notably, Costantini et al. [29] have found an increase of Ralstonia genus in cancerous samples relative to healthy-adjacent tissues from the same patient. Concomitantly, the authors have also reported decreased relative abundance of Methylobacterium in the cancerous samples, which is consistent with the findings of Wang et al. [10]. Costantini et al. [29] were the first to reveal that the genus Ralstonia, Proteobacteria phylum, is the most abundant genus in breast tissue since previously the genus had only been associated with human milk [85]. The findings of the increased relative abundance of Ralstonia in cancerous samples compared to healthy controls suggest possible pro-carcinogenic properties of the genus. Indeed, Ralstonia has been found to be correlated with most cancer types, including BC [86] and gastric cancer [87]. Therefore, it is plausible that the abundance of Ralstonia could be a biomarker of carcinogenesis. Furthermore, the interplay between racial differences and breast tissue microbiota in $\mathrm{BC}$ may suggest possible impact of genetics on the predisposition of the disease through its influence on the microbiota. Hence, further research is necessary to investigate on the correlation. On the other hand, NHW tumors were most enriched in order Xanthomonadales, which also belongs to the phylum Proteobacteria. In addition, Smith et al. [30] identified an enrichment of family Streptococcaceae in triple negative breast cancer and a greater abundance of genus Bosea (phylum Proteobacteria) that increased with stage.

\section{Potential anti-cancer properties of Sphingomonas yanoikuyae}

Xuan et al. [11] have demonstrated that microbial dysbiosis is associated with BC disease state and severity by investigating the breast tumor tissue and paired normal adjacent tissue of the same patient. In the study, Proteobacteria, Firmicutes, Bacteroidetes, Actinobacteria and Verrucomicrobia formed $96.6 \%$ of the microbiota composition. The tumor and paired normal tissue were found to be relatively enriched with the bacteria Methylobacterium radiotolerans (100\% of samples) and Sphingomonas yanoikuyae (95\% of samples) respectively [11]. S. yanoikuyae was not detected in the corresponding tumor tissue. The presence of $S$. yanoikuyae in normal breast tissue and its significantly lower abundance in corresponding tumor tissue indicates its possible anti-cancer function in the breast [11]. Indeed, S. yanoikuyae produces glycosphingolipid ligands, which serve as potent activators of invariant natural killer $\mathrm{T}$ (iNKT) cells [88]. These cells are crucial regulators in cancer immunosurveillance [89] and have been shown to have an essential role in controlling BC metastasis [90]. Consequently, the much lower abundance of S. yanoikuyae due to dysbiosis could result in reduced bacterial-dependent immune cell stimulation and lead to an environment susceptible to breast tumorigenesis [11]. Hence, further studies are required to explore the potential role of $S$. yanoikuyae in $\mathrm{BC}$ which may help to develop preventative strategies and new treatment options for the disease. Moreover, Costantini et al. [29] have reported a decrease in relative abundance of Sphingomonas in cancerous samples compared to their healthy counterparts in the same patients, substantiating its possible anti-cancer role. Nevertheless, the authors also revealed an increased relative abundance of Methylobacterium in the cancerous samples, although these results were not deemed statistically significant as they were not found in all patients of the study. Importantly, the presence of both Sphingomonas and Methylobacterium genera in Proteobacteria phylum was confirmed to be consistent with Xuan et al. [11], Urbaniak et al. [21] and Wang et al. [10]. 


\section{Association between breast cancer invasiveness with Methylobacterium and bacterial DNA load}

Methylobacterium radiotolerans was found in all samples in Xuan et al.'s study [11], but its absolute levels were not significantly varied between tumor and paired normal tissue. This indicates that its higher relative abundance in tumor tissue is resulted from the decrease of other bacteria. The relative abundances of both S. yanoikuyae and M. radiotolerans were only correlated inversely in paired normal tissue and not in tumor tissue, signifying that dysbiosis is related to BC. Nonetheless, the findings from Wang et al. [10] differ from those of Xuan et al. [11], whereby the relative abundance of the genus Methylobacterium (belonging to the phylum Proteobacteria) was significantly lower in breast tissue of BC patients. Although not statistically significant, the relative abundance of Methylobacterium in tumor tissue was lower than that of non-cancer control tissue and it was correlated to tumors with greater invasive potential [10]. This suggests that local depletion of the bacterium raises malignant potential. Thus, the abundance of the bacterium may be a potential biomarker for BC diagnosis and staging as well as a possible indicator of prognosis for the disease. Indeed, Methylobacterium produces phytohormones such as auxin and cytokinin [91], whereby some of these phytohormones exert anti-cancer effects $[92,93]$. The difference of the findings between these two studies $[10,11]$ may be due to a multitude of factors, including the methods used in tissue processing, DNA extraction and sequencing. Additionally, Wang et al. [10] reported no major shifts between paired normal tissue and invasive carcinoma in microbiomic content or overall diversity, consistent with the findings from Urbaniak et al. [24] but in contrast with Xuan et al. [11]. The authors also reported that the family Alcaligenaceae was more prevalent in cancer compared to non-cancer samples, in which some members of this family are human pathogens such as various species of Bordetella and Achromobacter, particularly in immunocompromised hosts [94]. Therefore, this may indicate a possible link between these pathogens and $\mathrm{BC}$, which warrants further investigations that could uncover novel mechanisms of breast carcinogenesis.

Moreover, Xuan et al. [11] revealed that the amount of bacteria in the healthy breast tissue from healthy controls and paired normal tissue from $B C$ patients were not significantly different in a quantitative analysis of breast microbiota. Nevertheless, the total bacterial DNA load in breast tumor was significantly lower than both of those tissues as determined through quantitative PCR (qPCR) in the analysis. Intriguingly, the bacterial DNA load was also found to be inversely correlated with advanced disease, which could be an additional indicator for the diagnosis and staging of BC. Thus, it can be speculated that a reduction in bacterial DNA load in a healthy individual indicates an increased risk of BC. Furthermore, Xuan et al. [11] have found that the basal levels of antibacterial response gene expression were lower in tumor when compared to healthy breast tissue. The significantly lower amount of bacteria in breast tumor tissue compared to paired normal and healthy breast tissues coincides with the decreased expression of one-third of antibacterial response genes examined by Xuan et al. [11]. The decreased expression levels of antimicrobial response effectors BPI, IL-12A and MPO as well as innate immune sensors such as TLR 2, 5 and 9 in the tumors indicate the role of bacteria in sustaining healthy breast tissue via stimulation of host inflammatory responses [11].

10. Conflicting role of lactic acid bacteria and Prevotella in breast cancer 
The lactic acid bacteria (LAB), Lactococcus and Streptococcus which are more prevalent in the healthy controls from Urbaniak et al.'s study [24], may possess anti-carcinogenic properties and could play a role in cancer prevention. Lactococcus lactis has been demonstrated to activate murine splenic natural killer (NK) cells and enhances cellular immunity [95]. Increased NK cell activity from peripheral blood mononuclear cells (PBMCs) has been associated with lower cancer risk [96]. Meanwhile, Streptococcus thermophilus produces antioxidant metabolites which neutralize peroxide and superoxide radicals, protecting better than other LAB tested against DNA damage induced by reactive oxygen species [97]. Indeed, an epidemiological study demonstrated that women who consume fermented milk products have lower risk of BC, regardless of multivariable risk factors [98]. This protection may be accredited to the health-promoting properties of LAB found in the fermented products. Therefore, the dysbiosis with increased levels of DNA-damaging bacteria and decreased levels of beneficial LAB in BC patients may potentially contribute to the breast carcinogenesis.

Nonetheless, one of the significant ways by which breast microbiota may affect oncogenesis is by increasing the local exposure of breast tissue to estrogen. In Thompson et al. [28] study, the most predominant phyla in the tumor samples were Proteobacteria (48.0\%), Actinobacteria (26.3\%) and Firmicutes (16.2\%), consistent with previous findings $[11,21,23]$. The Firmicutes were comprised of 13 substantial species, including the LAB, five Streptococcus spp. and two Lactobaccillus spp. Prior fecal studies revealed positive associations of the abundance of Streptococcus with the presence of $\beta$ glucosidase and $\beta$-glucuronidase enzymes, which cleave estrogen-glucuronide conjugate and enhance estrogen recirculation $[45,99]$. Systemic estrogen level is widely known to be implicated with increased $B C$ risk and glucuronidase prevalence has been recently implicated in nipple aspirate fluid of BC survivors [100]. Moreover, Thompson et al. [28] found that the expression profiles for the glucuronidase, beta pseudogenes 4 and 9 as well as glucosylceramidase beta 2 were positively linked with Streptococcus pyogenes. Increased abundances of S. pyogenes and Lactobaccillus rossiae were also observed in tumor samples. These evidences suggest that the abundances of LAB are correlated with $\mathrm{BC}$ development. Taken together, $\mathrm{LAB}$ was shown to possess conflicting roles in breast carcinogenesis and further studies are necessary to validate their roles in the disease.

Interestingly, Prevotella, which was more prevalent in healthy controls than in BC patients [24], also has a conflicting association with cancer. Prevotella generates, propionate, the short-chain fatty acid which is a beneficial microbial metabolite in the gut that can control colorectal tumor growth [101]. Higher levels of Prevotella were found in stool of healthy subjects than those with colorectal cancer in animal and human studies $[102,103]$. Conversely, higher levels of Prevotella is present in the oral cavity of patients with oral squamous cell carcinoma compared to healthy controls. In fact, Mager et al. [104] have used Prevotella presence as a diagnostic tool and predicted $80 \%$ of the cancer cases. Due to the unique microbiota present at each body site, a bacterium may perform differently in a different environment and play different roles at each body site. The conflicting role of Prevotella might be due to the metabolites which function differently at different body parts. Therefore, the role of Prevotella in breast tissue is yet to be determined. In addition, Urbaniak et al. [24] observed similar microbial profiles between normal adjacent tissue and tumor tissue as well as between normal adjacent tissue of the cancer and benign groups. This may indicate the presence of other factors which promotes malignancy and transformation of tumor in cancer patients that are reduced in women with benign tumors, such as higher levels of DNA-damaging bacteria or increased secretion of inflammatory and pro-angiogenic molecules. 


\section{Future directions}

Recent studies have confirmed the presence of microbiota in breast tissue, which was previously thought to be sterile, and provided an insight into the association between the microbiota and BC. However, the investigation of breast microbiota in BC patients is still in its infancy and future studies involving a larger sample size are required to validate these findings. Although the human microbiota may be specific in each individual, the human population shares a phylogenetic core formed by certain species of bacteria such as the commonly abundant phyla Proteobacteria and Firmicutes identified in breast tissue from different studies (Table 1). After validating the findings on breast microbiota, further research is necessary to determine the functional roles of bacteria which are differentially abundant in the breast tissue of patients with BC, benign tumors as well as healthy individuals. Some of the bacteria have been found to possess pro-carcinogenic properties and promote breast carcinogenesis, while others may protect against BC through their beneficial health effects. Indeed, a greater relative abundance of bacteria which caused DNA damage in vitro as well as a decrease in LAB which possess anti-carcinogenic properties were detected in BC patients, suggesting a potentially important role of breast microbiota in modulating the risk of the disease [24]. Nonetheless, it is possible that the healthy and diseased states are not driven by a single organism but an interplay of polymicrobial interactions.

Different bacterial signatures may be found in breast tissues of patients with different BC subtypes. In fact, bacterial signatures and information of the microbiota, such as bacterial DNA load, have been associated with $\mathrm{BC}$ invasiveness and could potentially be used in screening and diagnosis of the disease [11]. Additionally, examining other aspects of the breast microbiota, including bacterial metabolites as well as bacterially induced host metabolites could offer crucial information on breast health. Meanwhile, previous studies have shown that bacteria maintain breast health by stimulating resident immune cells [11] and thus, the effect of immunology in breast health should be further investigated. Notably, microbiota has also been found to affect the efficacy and toxicity of cancer treatments [60]. This signifies a novel strategy to exploit the microbiota to improve efficacy and reduce toxicity of cancer therapies. Importantly, by exploiting the knowledge on breast microbiota, preventative strategies or treatments can be implemented through modulation of the microbiota to create a less hospitable environment for cancer. This can be done through antibiotics which targets pro-carcinogenic bacteria as well as prebiotics or probiotics that protect against BC. Hence, this could serve as an adjuvant treatment or alternative to the existing cancer therapies, which have caused many undesirable side effects, to improve the prognosis and quality of life of $\mathrm{BC}$ patients. However, it was also found that antibiotics impact the microbiota, which in turn affect the efficacy of cancer therapies as well as the risk and recurrence of $\mathrm{BC}$ [70,75-79]. Therefore, any antibacterial therapy changing the microbiota equilibrium during the use of cancer therapy needs to be carefully assessed. In fact, depending on the composition and prevailing species of the heterogenous microbiota in patients, it can either be beneficial or detrimental to tumor progression and therapy. Hence, a personalized approach based on specific microbiota composition of the patients may be necessary in the future and further investigations on this aspect would be required.

It remains unclear whether the bacterial profile differences are the consequence or cause of $\mathrm{BC}$, which may require the use of germ-free animal models to reveal its role, although there has been evidence in favor of the latter in other diseases. Animal studies involving fecal transplants from those with colorectal cancer, colitis or obesity have caused the development of these diseases in healthy 
animals $[103,105,106]$. In addition, current studies on breast microbiota utilized a wide range of patient populations, sample processing, extraction techniques, amplification primers, sequencers and bioinformatics pipelines. Hence, it may be difficult to compare between the studies and further investigations are needed to determine which associations are strong enough to proceed with the following functional research. Interestingly, geographical and racial differences have been shown to influence breast tissue microbiota and correlate with BC $[21,30]$. Therefore, it may be valuable to explore further on these factors to establish the correlation which could potentially improve preventative and treatment strategies for the disease. Currently, various hypervariable regions of the 16S-rRNA gene, including V2, V3, V4, V6+7, V8 and V9 have been examined in breast microbiota studies. Importantly, Costantini et al. [29] have determined that the V3 region is the most informative compared to other regions for breast tissue microbiota. Thus, prioritizing the V3 region in future breast tissue microbiota studies may yield more information. In addition, the findings from the recent studies are potentially confounded by the effects of menopausal status, BMI, age and race of the human subjects. Therefore, clinically matched patients would provide more accurate analyses of the findings. Additionally, studies investigating the microbiota from other body sites, such as the gut, urinary tract, oral cavity and skin may identify other bacterial signatures which could serve as noninvasive biomarkers for diagnosis and aid in the development of BC treatments. It is also important to note that these much highlighted changes may interact with the breast microbiota to promote the health of the breast or act in concert to orchestrate BC development. Hence, this warrants further investigations to allow better understanding of the body-wide impacts of microbiota on BC.

\section{Conclusions}

Recent studies have shed light upon the relationship between breast microbiota and BC, whereby microbial dysbiosis is associated with the disease. Microbial signatures have been identified in the breast microbiota whereby certain bacterial species were found to possess pro-carcinogenic and/or anti-carcinogenic properties. Intriguingly, studies have also found correlation between breast tissue microbiota and other factors, such as geographical and racial differences, in BC. Furthermore, breast microbiota has been found to impact efficacy and toxicity of cancer treatments as well as the risk and recurrence of BC. Nonetheless, the study of breast microbiota and its association with BC is still in its infancy. Moving forward, further unravelling of the functionality of the microbial signatures would allow better understanding of its role in breast carcinogenesis and enable the development of screening tests, preventative strategies, diagnostic tools as well as treatments for BC.

Author Contributions: “Conceptualization, K.-Y.S., W.-L.L. and V.B.; methodology, K.-Y.S.; investigation, K.Y.S.; resources, V.B.; writing-original draft preparation, K.-Y.S.; writing - review and editing, K.-Y.S., W.-L.L. and V.B.; supervision, W.-L.L. and V.B.; project administration, V.B. All authors have read and agreed to the published version of the manuscript."

Funding: "This research received no external funding"

Acknowledgments: We would like to acknowledge School Research Office of Jeffrey Cheah School of Medicine and Health Sciences for their kind support for this project.

Conflicts of Interest: “The authors declare no conflict of interest."

\section{References}


1. Bray, F.; Ferlay, J.; Soerjomataram, I.; Siegel, R.L.; Torre, L.A.; Jemal, A. Global cancer statistics 2018: GLOBOCAN estimates of incidence and mortality worldwide for 36 cancers in 185 countries. CA: A Cancer Journal for Clinicians 2018, 68, 394-424, doi:10.3322/caac.21492.

2. Jemal, A.; Bray, F.; Center, M.M.; Ferlay, J.; Ward, E.; Forman, D. Global cancer statistics. CA: A Cancer Journal for Clinicians 2011, 61, 69-90, doi:10.3322/caac.20107.

3. Madigan, M.P.; Ziegler, R.G.; Benichou, J.; Byrne, C.; Hoover, R.N. Proportion of breast cancer cases in the United States explained by well-established risk factors. Journal of the National Cancer Institute 1995, 87, 1681-1685.

4. Pankratz, V.S.; Degnim, A.C.; Frank, R.D.; Frost, M.H.; Visscher, D.W.; Vierkant, R.A.; Hieken, T.J.; Ghosh, K.; Tarabishy, Y.; Vachon, C.M., et al. Model for Individualized Prediction of Breast Cancer Risk After a Benign Breast Biopsy. Journal of Clinical Oncology 2015, 33, 923-929, doi:10.1200/JCO.2014.55.4865.

5. Rockhill, B.; Spiegelman, D.; Byrne, C.; Hunter, D.J.; Colditz, G.A. Validation of the Gail et al. model of breast cancer risk prediction and implications for chemoprevention. Journal of the National Cancer Institute 2001, 93, 358-366.

6. Peterson, J.; Garges, S.; Giovanni, M.; McInnes, P.; Wang, L.; Schloss, J.A.; Bonazzi, V.; McEwen, J.E.; Wetterstrand, K.A.; Deal, C., et al. The NIH Human Microbiome Project. Genome Research 2009, 19, 2317-2323, doi:10.1101/gr.096651.109.

7. de la Cuesta-Zuluaga, J.; Corrales-Agudelo, V.; Velásquez-Mejía, E.P.; Carmona, J.A.; Abad, J.M.; Escobar, J.S. Gut microbiota is associated with obesity and cardiometabolic disease in a population in the midst of Westernization. Scientific Reports 2018, 8, 11356, doi:10.1038/s41598-018-29687-x.

8. Qiao, Y.; Wu, M.; Feng, Y.; Zhou, Z.; Chen, L.; Chen, F. Alterations of oral microbiota distinguish children with autism spectrum disorders from healthy controls. Scientific Reports 2018, 8, 1597, doi:10.1038/s41598-018-19982-y.

9. Strati, F.; Cavalieri, D.; Albanese, D.; De Felice, C.; Donati, C.; Hayek, J.; Jousson, O.; Leoncini, S.; Renzi, D.; Calabrò, A., et al. New evidences on the altered gut microbiota in autism spectrum disorders. Microbiome 2017, 5, 24, doi:10.1186/s40168-017-0242-1.

10. Wang, H.; Altemus, J.; Niazi, F.; Green, H.; Calhoun, B.C.; Sturgis, C.; Grobmyer, S.R.; Eng, C. Breast tissue, oral and urinary microbiomes in breast cancer. Oncotarget 2017, 8, 88122-88138, doi:10.18632/oncotarget.21490.

11. Xuan, C.; Shamonki, J.M.; Chung, A.; Dinome, M.L.; Chung, M.; Sieling, P.A.; Lee, D.J. Microbial dysbiosis is associated with human breast cancer. PloS one 2014, 9, e83744, doi:10.1371/journal.pone.0083744.

12. Amieva, M.R.; El-Omar, E.M. Host-Bacterial Interactions in Helicobacter pylori Infection. Gastroenterology 2008, 134, 306-323, doi:10.1053/j.gastro.2007.11.009.

13. Arthur, J.C.; Jobin, C. The complex interplay between inflammation, the microbiota and colorectal cancer. Gut Microbes 2013, 4, 253-258, doi:10.4161/gmic.24220.

14. Kostic, A.D.; Gevers, D.; Pedamallu, C.S.; Michaud, M.; Duke, F.; Earl, A.M.; Ojesina, A.I.; Jung, J.; Bass, A.J.; Tabernero, J., et al. Genomic analysis identifies association of Fusobacterium with colorectal carcinoma. Genome Research 2012, 22, 292-298, doi:10.1101/gr.126573.111.

15. de Martel, C.; Ferlay, J.; Franceschi, S.; Vignat, J.; Bray, F.; Forman, D.; Plummer, M. Global burden of cancers attributable to infections in 2008: a review and synthetic analysis. The Lancet Oncology 2012, 13, 607-615, doi:10.1016/S1470-2045(12)70137-7. 
16. Sawyers, C.L.; Abate-Shen, C.; Anderson, K.C.; Barker, A.; Baselga, J.; Berger, N.A.; Foti, M.; Jemal, A.; Lawrence, T.S.; Li, C.I., et al. AACR Cancer Progress Report 2013. Clinical Cancer Research 2013, 19, S1S98, doi:10.1158/1078-0432.CCR-13-2107.

17. Luu, T.H.; Michel, C.; Bard, J.-M.; Dravet, F.; Nazih, H.; Bobin-Dubigeon, C. Intestinal Proportion of $<\mathrm{i}>$ Blautia $</ \mathrm{i}>\mathrm{sp}$. is Associated with Clinical Stage and Histoprognostic Grade in Patients with EarlyStage Breast Cancer. Nutrition and Cancer 2017, 69, 267-275, doi:10.1080/01635581.2017.1263750. Fukase, K.; Kato, M.; Kikuchi, S.; Inoue, K.; Uemura, N.; Okamoto, S.; Terao, S.; Amagai, K.; Hayashi, S.; Asaka, M., et al. Effect of eradication of Helicobacter pylori on incidence of metachronous gastric carcinoma after endoscopic resection of early gastric cancer: an open-label, randomised controlled trial. The Lancet 2008, 372, 392-397, doi:10.1016/S0140-6736(08)61159-9.

19. Wotherspoon, A.C.; Doglioni, C.; Diss, T.C.; Pan, L.; Moschini, A.; de Boni, M.; Isaacson, P.G. Regression of primary low-grade B-cell gastric lymphoma of mucosa-associated lymphoid tissue type after eradication of Helicobacter pylori. Lancet (London, England) 1993, 342, 575-577.

20. Urbaniak, C.; Burton, J.P.; Reid, G. Breast, milk and microbes: a complex relationship that does not end with lactation. Women's health (London, England) 2012, 8, 385-398, doi:10.2217/whe.12.23.

21. Urbaniak, C.; Cummins, J.; Brackstone, M.; Macklaim, J.M.; Gloor, G.B.; Baban, C.K.; Scott, L.; O'Hanlon, D.M.; Burton, J.P.; Francis, K.P., et al. Microbiota of human breast tissue. Applied and environmental microbiology 2014, 80, 3007-3014, doi:10.1128/AEM.00242-14.

22. Donnet-Hughes, A.; Perez, P.F.; Doré, J.; Leclerc, M.; Levenez, F.; Benyacoub, J.; Serrant, P.; SeguraRoggero, I.; Schiffrin, E.J. Potential role of the intestinal microbiota of the mother in neonatal immune education. Proceedings of the Nutrition Society 2010, 69, 407-415, doi:10.1017/S0029665110001898.

23. Hieken, T.J.; Chen, J.; Hoskin, T.L.; Walther-Antonio, M.; Johnson, S.; Ramaker, S.; Xiao, J.; Radisky, D.C.; Knutson, K.L.; Kalari, K.R., et al. The Microbiome of Aseptically Collected Human Breast Tissue in Benign and Malignant Disease. Scientific Reports 2016, 6, 30751, doi:10.1038/srep30751.

24. Urbaniak, C.; Gloor, G.B.; Brackstone, M.; Scott, L.; Tangney, M.; Reid, G. The Microbiota of Breast Tissue and Its Association with Breast Cancer. Applied and environmental microbiology 2016, 82, 50395048, doi:10.1128/AEM.01235-16.

25. Banerjee, S.; Tian, T.; Wei, Z.; Shih, N.; Feldman, M.D.; Peck, K.N.; DeMichele, A.M.; Alwine, J.C.; Robertson, E.S. Distinct Microbial Signatures Associated With Different Breast Cancer Types. Frontiers in microbiology 2018, 9, 951, doi:10.3389/fmicb.2018.00951. Banerjee, S.; Wei, Z.; Tan, F.; Peck, K.N.; Shih, N.; Feldman, M.; Rebbeck, T.R.; Alwine, J.C.; Robertson, E.S. Distinct microbiological signatures associated with triple negative breast cancer. Scientific reports 2015, 5, 15162, doi:10.1038/srep15162.

27. Meng, S.; Chen, B.; Yang, J.; Wang, J.; Zhu, D.; Meng, Q.; Zhang, L. Study of Microbiomes in Aseptically Collected Samples of Human Breast Tissue Using Needle Biopsy and the Potential Role of in situ Tissue Microbiomes for Promoting Malignancy. Front Oncol 2018, 8, doi:10.3389/fonc.2018.00318.

Thompson, K.J.; Ingle, J.N.; Tang, X.; Chia, N.; Jeraldo, P.R.; Walther-Antonio, M.R.; Kandimalla, K.K.; Johnson, S.; Yao, J.Z.; Harrington, S.C., et al. A comprehensive analysis of breast cancer microbiota and host gene expression. PloS one 2017, 12, e0188873, doi:10.1371/journal.pone.0188873.

Costantini, L.; Magno, S.; Albanese, D.; Donati, C.; Molinari, R.; Filippone, A.; Masetti, R.; Merendino, $\mathrm{N}$. Characterization of human breast tissue microbiota from core needle biopsies through the analysis of multi hypervariable 16S-rRNA gene regions. Sci Rep 2018, 8, doi:10.1038/s41598-018-35329-z. 
30. Smith, A.; Pierre, J.F.; Makowski, L.; Tolley, E.; Lyn-Cook, B.; Lu, L.; Vidal, G.; Starlard-Davenport, A. Distinct microbial communities that differ by race, stage, or breast-tumor subtype in breast tissues of non-Hispanic Black and non-Hispanic White women. Sci Rep 2019, 9, 11940, doi:10.1038/s41598-01948348-1.

31. Lambert, A.W.; Pattabiraman, D.R.; Weinberg, R.A. Emerging Biological Principles of Metastasis. Cell 2017, 168, 670-691, doi:10.1016/j.cell.2016.11.037.

32. Moustakas, A.; de Herreros, A.G. Epithelial-mesenchymal transition in cancer. Mol Oncol 2017, 11, 715-717, doi:10.1002/1878-0261.12094.

33. Nieto, M.A.; Huang, R.Y.; Jackson, R.A.; Thiery, J.P. EMT: 2016. Cell 2016, 166, 21-45, doi:10.1016/j.cell.2016.06.028.

34. Chang, S.H.; Mirabolfathinejad, S.G.; Katta, H.; Cumpian, A.M.; Gong, L.; Caetano, M.S.; Moghaddam, S.J.; Dong, C. T helper 17 cells play a critical pathogenic role in lung cancer. Proceedings of the National Academy of Sciences 2014, 111, 5664-5669, doi:10.1073/pnas.1319051111.

35. Moghaddam, S.J.; Li, H.; Cho, S.-N.; Dishop, M.K.; Wistuba, I.I.; Ji, L.; Kurie, J.M.; Dickey, B.F.; DeMayo, F.J. Promotion of Lung Carcinogenesis by Chronic Obstructive Pulmonary Disease-Like Airway Inflammation in a K-ras-Induced Mouse Model. American Journal of Respiratory Cell and Molecular Biology 2009, 40, 443-453, doi:10.1165/rcmb.2008-0198OC.

36. Cavuoto, P.; Fenech, M.F. A review of methionine dependency and the role of methionine restriction in cancer growth control and life-span extension. Cancer Treatment Reviews 2012, 38, 726-736, doi:10.1016/j.ctrv.2012.01.004.

37. Hoffman, R.M. Development of recombinant methioninase to target the general cancer-specific metabolic defect of methionine dependence: a 40-year odyssey. Expert Opinion on Biological Therapy 2015, 15, 21-31, doi:10.1517/14712598.2015.963050.

38. Dumas, M.E. The microbial-mammalian metabolic axis: beyond simple metabolism. Cell metabolism 2011, 13, doi:10.1016/j.cmet.2011.04.005.

39. Wikoff, W.R.; Anfora, A.T.; Liu, J.; Schultz, P.G.; Lesley, S.A.; Peters, E.C.; Siuzdak, G. Metabolomics analysis reveals large effects of gut microflora on mammalian blood metabolites. Proceedings of the National Academy of Sciences of the United States of America 2009, 106, doi:10.1073/pnas.0812874106. Tao, J.; Li, S.; Gan, R.Y.; Zhao, C.N.; Meng, X.; Li, H.B. Targeting gut microbiota with dietary components on cancer: Effects and potential mechanisms of action. Critical reviews in food science and nutrition 2020, 60, doi:10.1080/10408398.2018.1555789.

41. Thirunavukkarasan, M.; Wang, C.; Rao, A.; Hind, T.; Teo, Y.R.; Siddiquee, A.A.-M.; Goghari, M.A.I.; Kumar, A.P.; Herr, D.R. Short-chain fatty acid receptors inhibit invasive phenotypes in breast cancer cells. PloS one 2017, 12, e0186334.

42. Goldberg, A.A.; Beach, A.; Davies, G.F.; Harkness, T.A.; LeBlanc, A.; Titorenko, V.I. Lithocholic bile acid selectively kills neuroblastoma cells, while sparing normal neuronal cells. Oncotarget 2011, 2, 761.

43. Luu, T.H.; Bard, J.-M.; Carbonnelle, D.; Chaillou, C.; Huvelin, J.-M.; Bobin-Dubigeon, C.; Nazih, H. Lithocholic bile acid inhibits lipogenesis and induces apoptosis in breast cancer cells. Cellular Oncology 2018, 41, 13-24.

44. Mikó, E.; Vida, A.; Kovács, T.; Ujlaki, G.; Trencsényi, G.; Márton, J.; Sári, Z.; Kovács, P.; Boratkó, A.; Hujber, Z. Lithocholic acid, a bacterial metabolite reduces breast cancer cell proliferation and aggressiveness. Biochimica et Biophysica Acta (BBA)-Bioenergetics 2018, 1859, 958-974. 
45. Flores, R.; Shi, J.; Fuhrman, B.; Xu, X.; Veenstra, T.D.; Gail, M.H.; Gajer, P.; Ravel, J.; Goedert, J.J. Fecal microbial determinants of fecal and systemic estrogens and estrogen metabolites: a cross-sectional study. Journal of Translational Medicine 2012, 10, 253, doi:10.1186/1479-5876-10-253.

Fuhrman, B.J.; Feigelson, H.S.; Flores, R.; Gail, M.H.; Xu, X.; Ravel, J.; Goedert, J.J. Associations of the Fecal Microbiome With Urinary Estrogens and Estrogen Metabolites in Postmenopausal Women. The Journal of Clinical Endocrinology \& Metabolism 2014, 99, 4632-4640, doi:10.1210/jc.2014-2222. Kovács, T.; Mikó, E.; Vida, A.; Sebő, É.; Toth, J.; Csonka, T.; Boratkó, A.; Ujlaki, G.; Lente, G.; Kovács, P. Cadaverine, a metabolite of the microbiome, reduces breast cancer aggressiveness through trace amino acid receptors. Scientific reports 2019, 9, 1-14.

48. Kulkoyluoglu-Cotul, E.; Arca, A.; Madak-Erdogan, Z. Crosstalk between estrogen signaling and breast cancer metabolism. Trends in Endocrinology E Metabolism 2019, 30, 25-38.

49. Cuevas-Ramos, G.; Petit, C.R.; Marcq, I.; Boury, M.; Oswald, E.; Nougayrede, J.-P. Escherichia coli induces DNA damage in vivo and triggers genomic instability in mammalian cells. Proceedings of the National Academy of Sciences 2010, 107, 11537-11542, doi:10.1073/pnas.1001261107.

50. Nougayrede, J.-P.; Homburg, S.; Taieb, F.; Boury, M.; Brzuszkiewicz, E.; Gottschalk, G.; Buchrieser, C.; Hacker, J.; Dobrindt, U.; Oswald, E. Escherichia coli Induces DNA Double-Strand Breaks in Eukaryotic Cells. Science 2006, 313, 848-851, doi:10.1126/science.1127059.

51. Arthur, J.C.; Perez-Chanona, E.; Muhlbauer, M.; Tomkovich, S.; Uronis, J.M.; Fan, T.-J.; Campbell, B.J.; Abujamel, T.; Dogan, B.; Rogers, A.B., et al. Intestinal Inflammation Targets Cancer-Inducing Activity of the Microbiota. Science 2012, 338, 120-123, doi:10.1126/science.1224820.

52. Buc, E.; Dubois, D.; Sauvanet, P.; Raisch, J.; Delmas, J.; Darfeuille-Michaud, A.; Pezet, D.; Bonnet, R. High Prevalence of Mucosa-Associated E. coli Producing Cyclomodulin and Genotoxin in Colon Cancer. PLOS ONE 2013, 8, e56964, doi:10.1371/journal.pone.0056964.

53. Ojanotko-Harri, A.; Nikkari, T.; Harri, M.P.; Paunio, K.U. Metabolism of progesterone and testosterone by Bacillus cereus strain Socransky 67 and Streptococcus mutans strain Ingbritt. Oral microbiology and immunology 1990, 5, 237-239.

54. Wiebe, J.P.; Muzia, D.; Hu, J.; Szwajcer, D.; Hill, S.A.; Seachrist, J.L. The 4-pregnene and 5alphapregnane progesterone metabolites formed in nontumorous and tumorous breast tissue have opposite effects on breast cell proliferation and adhesion. Cancer research 2000, 60, 936-943. Burns, M.B.; Lynch, J.; Starr, T.K.; Knights, D.; Blekhman, R. Virulence genes are a signature of the microbiome in the colorectal tumor microenvironment. Genome Medicine 2015, 7, 55, doi:10.1186/s13073-015-0177-8.

56. Castellarin, M.; Warren, R.L.; Freeman, J.D.; Dreolini, L.; Krzywinski, M.; Strauss, J.; Barnes, R.; Watson, P.; Allen-Vercoe, E.; Moore, R.A., et al. Fusobacterium nucleatum infection is prevalent in human colorectal carcinoma. Genome Research 2012, 22, 299-306, doi:10.1101/gr.126516.111. Marchesi, J.R.; Dutilh, B.E.; Hall, N.; Peters, W.H.M.; Roelofs, R.; Boleij, A.; Tjalsma, H. Towards the human colorectal cancer microbiome. PloS one 2011, 6, e20447, doi:10.1371/journal.pone.0020447. Schwabe, R.F.; Jobin, C. The microbiome and cancer. Nature reviews. Cancer 2013, 13, doi:10.1038/nrc3610. 
60. Alexander, J.L.; Wilson, I.D.; Teare, J.; Marchesi, J.R.; Nicholson, J.K.; Kinross, J.M. Gut microbiota modulation of chemotherapy efficacy and toxicity. Nat Rev Gastroenterol Hepatol 2017, 14, 356-365, doi:10.1038/nrgastro.2017.20.

61. Chaput, N.; Lepage, P.; Coutzac, C.; Soularue, E.; Le Roux, K.; Monot, C.; Boselli, L.; Routier, E.; Cassard, L.; Collins, M., et al. Baseline gut microbiota predicts clinical response and colitis in metastatic melanoma patients treated with ipilimumab. Annals of oncology : official journal of the European Society for Medical Oncology 2017, 28, doi:10.1093/annonc/mdx108.

62. E., F.A.; Coughlin, L.A.; Kim, J.; Froehlich, T.W.; Xie, Y.; Frenkel, E.P.; Koh, A.Y. Metagenomic Shotgun Sequencing and Unbiased Metabolomic Profiling Identify Specific Human Gut Microbiota and Metabolites Associated with Immune Checkpoint Therapy Efficacy in Melanoma Patients. Neoplasia (New York, N.Y.) 2017, 19, doi:10.1016/j.neo.2017.08.004.

63. Sonis, S.T. The Chicken or the Egg? Changes in Oral Microbiota as Cause or Consequence of Mucositis During Radiation Therapy. EBioMedicine 2017, 18, 7-8, doi:10.1016/j.ebiom.2017.03.017. Zhu, X.X.; Yang, X.J.; Chao, Y.L.; Zheng, H.M.; Sheng, H.F.; Liu, H.Y.; He, Y.; Zhou, H.W. The Potential Effect of Oral Microbiota in the Prediction of Mucositis During Radiotherapy for Nasopharyngeal Carcinoma. EBioMedicine 2017, 18, 23-31, doi:10.1016/j.ebiom.2017.02.002.

65. Cui, M.; Xiao, H.; Li, Y.; Zhou, L.; Zhao, S.; Luo, D.; Zheng, Q.; Dong, J.; Zhao, Y.; Zhang, X., et al. Faecal microbiota transplantation protects against radiation-induced toxicity. EMBO Mol Med 2017, 9 , 448-461, doi:10.15252/emmm.201606932.

66. Curtin, N.J.; Szabo, C. Therapeutic applications of PARP inhibitors: anticancer therapy and beyond. Mol Aspects Med 2013, 34, 1217-1256, doi:10.1016/j.mam.2013.01.006.

67. Fong, P.C.; Boss, D.S.; Yap, T.A.; Tutt, A.; Wu, P.; Mergui-Roelvink, M.; Mortimer, P.; Swaisland, H.; Lau, A.; O'Connor, M.J., et al. Inhibition of poly(ADP-ribose) polymerase in tumors from BRCA mutation carriers. N Engl J Med 2009, 361, 123-134, doi:10.1056/NEJMoa0900212.

68. Larmonier, C.B.; Shehab, K.W.; Laubitz, D.; Jamwal, D.R.; Ghishan, F.K.; Kiela, P.R. Transcriptional Reprogramming and Resistance to Colonic Mucosal Injury in Poly(ADP-ribose) Polymerase 1 (PARP1)-deficient Mice. J Biol Chem 2016, 291, 8918-8930, doi:10.1074/jbc.M116.714386.

69. Vida, A.; Kardos, G.; Kovacs, T.; Bodrogi, B.L.; Bai, P. Deletion of poly(ADPribose) polymerase-1 changes the composition of the microbiome in the gut. Mol Med Rep 2018, 18, 4335-4341, doi:10.3892/mmr.2018.9474.

70. Iida, N.; Dzutsev, A.; Stewart, C.A.; Smith, L.; Bouladoux, N.; Weingarten, R.A.; Molina, D.A.; Salcedo, R.; Back, T.; Cramer, S., et al. Commensal bacteria control cancer response to therapy by modulating the tumor microenvironment. Science 2013, 342, 967-970, doi:10.1126/science.1240527.

71. Gui, Q.F.; Lu, H.F.; Zhang, C.X.; Xu, Z.R.; Yang, Y.H. Well-balanced commensal microbiota contributes to anti-cancer response in a lung cancer mouse model. Genetics and molecular research : GMR 2015, 14, doi:10.4238/2015.May.25.16.

72. Routy, B.; Le Chatelier, E.; Derosa, L.; Duong, C.P.M.; Alou, M.T.; Daillère, R.; Fluckiger, A.; Messaoudene, M.; Rauber, C.; Roberti, M.P., et al. Gut microbiome influences efficacy of PD-1-based immunotherapy against epithelial tumors. Science (New York, N.Y.) 2018, 359, doi:10.1126/science.aan3706.

73. Gopalakrishnan, V.; Spencer, C.N.; Nezi, L.; Reuben, A.; Andrews, M.C.; Karpinets, T.V.; Prieto, P.A.; Vicente, D.; Hoffman, K.; Wei, S.C., et al. Gut microbiome modulates response to anti-PD-1 immunotherapy in melanoma patients. Science (New York, N.Y.) 2018, 359, doi:10.1126/science.aan4236. 
74. Matson, V.; Fessler, J.; Bao, R.; Chongsuwat, T.; Zha, Y.; Alegre, M.L.; Luke, J.J.; Gajewski, T.F. The commensal microbiome is associated with anti-PD-1 efficacy in metastatic melanoma patients. Science (New York, N.Y.) 2018, 359, doi:10.1126/science.aao3290.

75. Friedman, G.D.; Oestreicher, N.; Chan, J.; Quesenberry, C.P., Jr.; Udaltsova, N.; Habel, L.A.

Antibiotics and risk of breast cancer: up to 9 years of follow-up of 2.1 million women. Cancer Epidemiol Biomarkers Prev 2006, 15, 2102-2106, doi:10.1158/1055-9965.epi-06-0401.

76. Tamim, H.M.; Hanley, J.A.; Hajeer, A.H.; Boivin, J.F.; Collet, J.P. Risk of breast cancer in relation to antibiotic use. Pharmacoepidemiol Drug Saf 2008, 17, 144-150, doi:10.1002/pds.1512.

77. Velicer, C.M.; Heckbert, S.R.; Lampe, J.W.; Potter, J.D.; Robertson, C.A.; Taplin, S.H. Antibiotic Use in Relation to the Risk of Breast Cancer. JAMA 2004, 291, 827-835, doi:10.1001/jama.291.7.827.

78. Velicer, C.M.; Heckbert, S.R.; Rutter, C.; Lampe, J.W.; Malone, K. Association between antibiotic use prior to breast cancer diagnosis and breast tumour characteristics (United States). Cancer Causes Control 2006, 17, 307-313, doi:10.1007/s10552-005-0445-9.

79. Wirtz, H.S.; Buist, D.S.; Gralow, J.R.; Barlow, W.E.; Gray, S.; Chubak, J.; Yu, O.; Bowles, E.J.; Fujii, M.; Boudreau, D.M. Frequent antibiotic use and second breast cancer events. Cancer Epidemiol Biomarkers Prev 2013, 22, 1588-1599, doi:10.1158/1055-9965.epi-13-0454.

80. Fessler, J.L.; Gajewski, T.F. The Microbiota: A New Variable Impacting Cancer Treatment Outcomes. Clinical cancer research : an official journal of the American Association for Cancer Research 2017, 23, doi:10.1158/1078-0432.CCR-17-0864.

81. Nayak, R.R.; Turnbaugh, P.J. Mirror, mirror on the wall: which microbiomes will help heal them all? BMC medicine 2016, 14, doi:10.1186/s12916-016-0622-6.

82. DeSantis, C.E.; Ma, J.; Goding Sauer, A.; Newman, L.A.; Jemal, A. Breast cancer statistics, 2017, racial disparity in mortality by state. CA Cancer J Clin 2017, 67, 439-448, doi:10.3322/caac.21412.

83. Sineshaw, H.M.; Gaudet, M.; Ward, E.M.; Flanders, W.D.; Desantis, C.; Lin, C.C.; Jemal, A. Association of race/ethnicity, socioeconomic status, and breast cancer subtypes in the National Cancer Data Base (2010-2011). Breast Cancer Res Treat 2014, 145, 753-763, doi:10.1007/s10549-014-2976-9.

84. Vidal, G.; Bursac, Z.; Miranda-Carboni, G.; White-Means, S.; Starlard-Davenport, A. Racial disparities in survival outcomes by breast tumor subtype among African American women in Memphis, Tennessee. Cancer Med 2017, 6, 1776-1786, doi:10.1002/cam4.1117.

85. Hunt, K.M.; Foster, J.A.; Forney, L.J.; Schutte, U.M.; Beck, D.L.; Abdo, Z.; Fox, L.K.; Williams, J.E.; McGuire, M.K.; McGuire, M.A. Characterization of the diversity and temporal stability of bacterial communities in human milk. PLoS One 2011, 6, e21313, doi:10.1371/journal.pone.0021313.

86. Robinson, K.M.; Crabtree, J.; Mattick, J.S.A.; Anderson, K.E.; Dunning Hotopp, J.C. Distinguishing potential bacteria-tumor associations from contamination in a secondary data analysis of public cancer genome sequence data. Microbiome 2017, 5, doi:10.1186/s40168-016-0224-8.

87. Tseng, C.H.; Lin, J.T.; Ho, H.J.; Lai, Z.L.; Wang, C.B.; Tang, S.L.; Wu, C.Y. Gastric microbiota and predicted gene functions are altered after subtotal gastrectomy in patients with gastric cancer. Sci Rep 2016, 6, 20701, doi:10.1038/srep20701.

88. Kinjo, Y.; Wu, D.; Kim, G.; Xing, G.-W.; Poles, M.A.; Ho, D.D.; Tsuji, M.; Kawahara, K.; Wong, C.-H.; Kronenberg, M. Recognition of bacterial glycosphingolipids by natural killer T cells. Nature 2005, 434, 520-525, doi:10.1038/nature03407.

89. Terabe, M.; Berzofsky, J.A. NKT cells in immunoregulation of tumor immunity: a new immunoregulatory axis. Trends in Immunology 2007, 28, 491-496, doi:10.1016/j.it.2007.05.008. 
90. Hix, L.M.; Shi, Y.H.; Brutkiewicz, R.R.; Stein, P.L.; Wang, C.-R.; Zhang, M. CD1d-Expressing Breast Cancer Cells Modulate NKT Cell-Mediated Antitumor Immunity in a Murine Model of Breast Cancer Metastasis. PLoS ONE 2011, 6, e20702, doi:10.1371/journal.pone.0020702.

91. Kutschera, U. Plant-associated methylobacteria as co-evolved phytosymbionts: a hypothesis. Plant signaling \& behavior 2007, 2, 74-78. Ishii, Y.; Sakai, S.; Honma, Y. Cytokinin-induced differentiation of human myeloid leukemia HL-60 cells is associated with the formation of nucleotides, but not with incorporation into DNA or RNA. Biochimica et biophysica acta 2003, 1643, 11-24.

93. Pollock, C.B.; Koltai, H.; Kapulnik, Y.; Prandi, C.; Yarden, R.I. Strigolactones: a novel class of phytohormones that inhibit the growth and survival of breast cancer cells and breast cancer stem-like enriched mammosphere cells. Breast Cancer Research and Treatment 2012, 134, 1041-1055, doi:10.1007/s10549-012-1992-x.

94. Austin, B. The Family Alcaligenaceae. In The Prokaryotes, Springer Berlin Heidelberg: Berlin, Heidelberg, 2014; 10.1007/978-3-642-30197-1_397pp 729-757.

95. Kosaka, A.; Yan, H.; Ohashi, S.; Gotoh, Y.; Sato, A.; Tsutsui, H.; Kaisho, T.; Toda, T.; Tsuji, N.M. Lactococcus lactis subsp. cremoris FC triggers IFN- $\gamma$ production from NK and T cells via IL-12 and IL-18. International Immunopharmacology 2012, 14, 729-733, doi:10.1016/j.intimp.2012.10.007.

96. Imai, K.; Matsuyama, S.; Miyake, S.; Suga, K.; Nakachi, K. Natural cytotoxic activity of peripheralblood lymphocytes and cancer incidence: an 11-year follow-up study of a general population. The Lancet 2000, 356, 1795-1799, doi:10.1016/S0140-6736(00)03231-1.

97. Koller, V.J.; Marian, B.; Stidl, R.; Nersesyan, A.; Winter, H.; Simić, T.; Sontag, G.; Knasmüller, S. Impact of lactic acid bacteria on oxidative DNA damage in human derived colon cells. Food and Chemical Toxicology 2008, 46, 1221-1229, doi:10.1016/j.fct.2007.09.005.

98. van't Veer, P.; Dekker, J.M.; Lamers, J.W.; Kok, F.J.; Schouten, E.G.; Brants, H.A.; Sturmans, F.; Hermus, R.J. Consumption of fermented milk products and breast cancer: a case-control study in The Netherlands. Cancer research 1989, 49, 4020-4023.

99. Flores, R.; Shi, J.; Gail, M.H.; Gajer, P.; Ravel, J.; Goedert, J.J. Association of fecal microbial diversity and taxonomy with selected enzymatic functions. PloS one 2012, 7, e39745, doi:10.1371/journal.pone.0039745.

100. Chan, A.A.; Bashir, M.; Rivas, M.N.; Duvall, K.; Sieling, P.A.; Pieber, T.R.; Vaishampayan, P.A.; Love, S.M.; Lee, D.J. Characterization of the microbiome of nipple aspirate fluid of breast cancer survivors. Scientific Reports 2016, 6, 28061, doi:10.1038/srep28061.

101. Hosseini, E.; Grootaert, C.; Verstraete, W.; Van de Wiele, T. Propionate as a health-promoting microbial metabolite in the human gut. Nutrition Reviews 2011, 69, 245-258, doi:10.1111/j.17534887.2011.00388.x.

102. Weir, T.L.; Manter, D.K.; Sheflin, A.M.; Barnett, B.A.; Heuberger, A.L.; Ryan, E.P. Stool Microbiome and Metabolome Differences between Colorectal Cancer Patients and Healthy Adults. PLoS ONE 2013, 8, e70803, doi:10.1371/journal.pone.0070803.

103 Zackular, J.P.; Baxter, N.T.; Iverson, K.D.; Sadler, W.D.; Petrosino, J.F.; Chen, G.Y.; Schloss, P.D. The gut microbiome modulates colon tumorigenesis. mBio 2013, 4, e00692-00613, doi:10.1128/mBio.0069213.

104. Mager, D.; Haffajee, A.; Devlin, P.; Norris, C.; Posner, M.; Goodson, J. The salivary microbiota as a diagnostic indicator of oral cancer: a descriptive, non-randomized study of cancer-free and oral 
squamous cell carcinoma subjects. Journal of Translational Medicine 2005, 3, 27, doi:10.1186/1479-5876-327.

105. Garrett, W.S.; Lord, G.M.; Punit, S.; Lugo-Villarino, G.; Mazmanian, S.K.; Ito, S.; Glickman, J.N.; Glimcher, L.H. Communicable ulcerative colitis induced by T-bet deficiency in the innate immune system. Cell 2007, 131, 33-45, doi:10.1016/j.cell.2007.08.017.

106. Turnbaugh, P.J.; Hamady, M.; Yatsunenko, T.; Cantarel, B.L.; Duncan, A.; Ley, R.E.; Sogin, M.L.; Jones, W.J.; Roe, B.A.; Affourtit, J.P., et al. A core gut microbiome in obese and lean twins. Nature 2009, 457, 480-484, doi:10.1038/nature07540. 